\title{
Importance of Anaplastic Lymphoma Kinase Gene Re-arrangements on Non-Small Cell Lung Cancer
}

\author{
Küçük Hücreli DıșI Akciğer Kanserinde Anaplastik Lenfoma Kinaz Gen Yeniden Düzenlemelerinin Önemi
}

\author{
Ayșe Feyda Nursal \\ Hitit Üniversitesi Tip Fakültesi, Tibbi Genetik Anabilim Dalı, Çorum,Türkiye
}

\begin{abstract}
Despite all improvements in treatment modalities, lung cancer is the leading cause of death related to cancers worldwide. Environmental, occupational and genetic factors, as well as smoking play role in the etiology. Lung cancers are generally divided into two main histologic categories: small cell lung cancer (SCLC) and non-small cell lung cancer (NSCLC). Several gene aberrations are detected in NSCLC, which constitute approximately $85 \%$ of all lung cancers. The Anaplastic lymphoma kinase (ALK) gene is a member of insulin receptor tyrosine kinase super family. ALK gene involves with translocation those results in formation of fusion protein in various malignancies such as lung cancer and lymphoma. In this article, latest literature regarding re-arrangement of ALK seen in NSCLC will be reviewed.
\end{abstract}

Key words: lung cancer; non-small cell lung cancer; ALK gene; gene rearrangements; EML4/ALK fusion

\section{ÖZET}

Tedavi alanındaki tüm gelișmelere rağmen, akciğer kanseri hala tüm dünyada kanserle ilișkili ölüm nedenlerinin bașında gelmektedir. Etyolojisinde sigaranın yanı sıra çevresel, mesleksel ve genetik faktörler rol oynamaktadır. Akciğer kanserleri genellikle küçük hücreli akciğer kanseri (KHAK) ve küçük hücreli dıșı akciğer kanseri (KHDAK) olmak üzere iki ana histolojik tipe ayrılır. Tüm akciğer kanserlerinin yaklașık \%85'ini olușturan KHDAK'inde birçok gen anomalisi saptanır. Anaplastik lenfoma kinaz (ALK) geni insülin reseptör tirozin kinaz süper ailesinin bir üyesidir. ALK geni akciğer kanseri, lenfoma gibi çeșitli malignitelerde füsyon protein olușumuna yol açan translokasyonlara dahil olur. Bu derlemede KHDAK'inde görülen ALK yeniden düzenlenmelerine ait son literatür gözden geçirilecektir.

Anahtar kelimeler: akciğer kanseri; küçük hücreli dıșı akciğer kanseri; ALK geni; gen yeniden düzenlenmeleri; EML4/ALK füzyon

Ayse Feyda Nursal, Hitit Üniversitesi T⿰р Fakültesi, Tibbi Genetik Anabilim Dal, Çorum - Türkiye, Tel.03642221100 Email.feydanursal@hotmail.com Geliş Taribi: 23.05.2015 • Kabul Taribi: 22.05.2017

\section{Introduction}

Lung cancer is an important public health issue that is leading cause of deaths related to cancer ${ }^{1}$. Lung cancer is a complex disease that develops with interaction of different etiologic factors. Smoking is the most important risk factor, however environmental, occupational exposure and genetic factors also have a role ${ }^{2}$. Lung cancers are divided into two main histologic types as small cell lung cancer (SCLC) (15\%) and non-small cell lung cancer (NSCLC) $(85 \%)^{3}$. Target-oriented and whole genome association studies showed that multi-step changes at expression level of different subtypes of lung cancer affects different oncogenic pathways. Tumoral heterogeneity that is seen in lung cancers arises from different histologic and molecular structures that can affect the treatment ${ }^{1}$. Many gene aberrations are seen in NSCLC including Kirsten rat sarcoma viral oncogene homolog (KRAS), epidermal growth factor receptor (EGFR), Raf murine sarcoma viral oncogene homolog B1 (BRAF), Human epidermal growth factor receptor 2 (HER2), Proto-oncogene C-Met (MET), Anaplastic lymphoma kinase (ALK), Ret proto-oncogene (RET) gene. In this article, latest literature regarding rearrangement of ALK gene seen in NSCLC will be reviewed.

\section{Non-Small Cell Lung Cancer (NSCLC)}

NSCLC, that forms the majority of the lung cancers, is divided into three histologic subtypes as adenocarcinoma (AC), squamous cell carcinoma (SCC) and large cell carcinoma. AC and SCC constitute more than $70 \%$ of the cases with NSCLC ${ }^{3}$. Although histologic subtypes manifest many similar biological characteristics, their cellular origins, their locations in the lungs, changes in their growth features suggest that they occur via different molecular mechanisms ${ }^{3}$. Most of the patients with NSCLC are in advanced stage at the time of diagnosis. 
It displays an aggressive clinical prognosis and it bears a high potential for metastasis. Therefore, overall prognosis is poor. Disease is usually in advanced stage at the time of diagnosis and 5 year-survival rate is rather low $(5-10 \%)^{1}$. Efficiency of agents used in chemotherapy is low. The average survival is 7.15 months in untreated advanced-stage NSCLC, while it is $8-12$ months in patients who receive cytotoxic platinum-based chemotherapy. Changes in approximately 140 genes were detected in studies regarding mechanisms of carcinogenesis in previous decades. They have a "driver mutation" function on initiation and progression of malignancy. In most of adult malignancies, 33-36 driver mutation is found, and this reaches 200 mutation in NSCLC with addition of mutagenic agents such as cigarettes ${ }^{4}$.

Recently, it was found that NSCLC subtypes treated with standard chemotherapeutic agents showed different genetic changes and this in turn affects response to therapy and progression-free survival (PFS). Therefore, treatment protocols intended for histologic type have come into question ${ }^{5}$. Our knowledge on initiator mutations seen in NSCLC was increased with the use of high throughput screening techniques. Detection of activating mutations in EGFR kinase domain has been particularly instructive. Improvement in response to treatment and progression-free survival was achieved with use of EGFR-tyrosine kinase inhibitors (EGFR-TKIs) compared to standard chemotherapeutic agents. Today purpose of cancer treatment is to provide individual-specific treatment with knowledge of tumor molecular changes.

\section{Anaplastic Lymphoma Kinase (ALK) Gene}

ALK is localized in 2p23.2 and consists of 29 exons. This gene, a member of insulin receptor protein-tyrosine kinase super family, codes a $220 \mathrm{kDa}$ protein ${ }^{6}$. ALK gene was first identified by Morris et al. in 1994 as a result of translocation made with nucleophosmin on large cell lymphoma cell line t $(2 ; 5)(\mathrm{p} 23 ; \mathrm{q} 35)^{7}$. This chromosomal rearrangement results in ectopic expression of NPM-ALK fusion protein that activates kinase domain of the ALK gene ${ }^{6}$.

The ALK protein consists of three main parts including an extracellular ligand-binding domain, a transmembrane domain and a single intracellular tyrosine kinase domain. Tyrosine residues are phosphorylated following activation of ALK through dimerization ${ }^{4}$.

ALK protein acts on neuronal development and differentiation during embryogenesis in mammalians. It is reported that ALK mRNA is expressed in human brain, testis, prostate and colon, however it is not expressed in spleen, lungs, ovaries, placenta, liver, skeletal muscle, kidneys, lymphoid tissue and pancreas ${ }^{6}$. Active ALK Janus kinase, which is a mammalian target of rapamycin, induces several signal transmission pathways cush as sonic hedgehog, hypoxia-inducible factor- $1 \alpha$, JUNB, and phospholipase signaling ${ }^{4}$.

ALK gene activation occurs through three distinct mechanisms involving i) fusion protein formation, ii) ALK overexpression, and iii) activating ALK point mutations. While one of these mutations is observed in histologically identified cancers, two types of mutations can be seen in NSCLC. Fusion partner in ALK translocations regulates the level of ALK expression, cellular location and time of its expression ${ }^{4}$. Intracellular kinase domain of ALK and terminal end points of different genes make up the fusion protein.

Twenty-two distinct translocation partners that are known to form fusion protein with ALK exist ${ }^{4}$. In lung cancer, fusion with Echinoderm microtubule-associated protein-like 4 (EML4) gene was detected first and TFG-ALK, KIF5-ALK fusions followed. ALK gene mutations are seen in several cancers including anaplastic large cell lymphoma, diffuse large B cell lymphoma, neuroblastoma, inflammatory myofibroblastic tumor, lobular breast cancer, colorectal cancer, renal cell carcinoma, esophageal squamous cell carcinoma and NSCLC adenocarcinoma ${ }^{4}$.

\section{ALK Gene in NSCLC}

ALK-EML4 rearrangement in NSCL was defined in Japanese patients in 2007 by Soda et al. ${ }^{8}$. Both EML4 and ALK gene are located on the short arm of the chromosome 2 , and fusion formation occurs with the inversion in $\mathrm{p}$ arm of the chromosome $2^{9}, \mathrm{~N}$-terminal domain of the EML4 and intracellular kinase domain of the ALK gene forms a fusion, and a continuously active ALK tyrosine kinase effect arises. EML4-ALK fusion activates the downstream RAS/RAF/MEK, $\mathrm{PI} 3 \mathrm{~K} / \mathrm{AKT} / \mathrm{mTOR}$ and Janus kinase (JAK)/STAT signal pathways that will lead to cellular proliferation, invasion and inhibition of apoptosis ${ }^{1}$.

Multiple variants of EML4-ALK have been reported (Table 1). They encode the same intracellular tyrosine kinase domain of ALK, but different truncations of EML $4^{10}$. The most common variants are variant 1 (detected in 33\% of NSCLC patients) which results in the juxtaposition of exon 13 of EML 4 to exon 20 of ALK (E13; A20) and variant 3a/b (29\% of NSCLC 
Table 1. EML4-ALK fusion variants

\begin{tabular}{ll}
\hline E13; A20 & E18; A20 \\
E6a/b; A20 & E15; A20 \\
E20; A20 & E2; A20 \\
E14;A20 & E17; A20 \\
\hline
\end{tabular}

patients) in which exon 6 of EML 4 is integrated into exon 20 of $\operatorname{ALK}(\mathrm{E} 6 \mathrm{a} / \mathrm{b} ; \mathrm{A} 20)^{10}$.

Diverse variants of EML4-ALK proteins can manifest different enzymatic activity. ALK also has multiple fusion partner that display different molecular weight, protein stability and ALK inhibitor sensitiviy ${ }^{4}$. In monkey models, it was found that EML4-ALK fusion gene showed oncogenic activity ${ }^{8}$. EML4-ALK appears rare in lung cancer and has been detected in about only 3-8\% of NSCLC cases $^{11}$. EML4-ALK fusion bears distinct pathological and demographic characteristics. One of the most striking features of EML4-ALKpositive lung cancers is early age $(\sim 50)$ of onset $^{12}$.

EML4-ALK fusion in NSCLC is more common in adenocarcinomas and non-smokers or light-smokers ${ }^{12}$. Preclinical and clinical studies showed that cancer cells with EML4-ALK or other ALK anomalies are rather sensitive to ALK inhibitor drugs ${ }^{13}$.

\section{ALK Testing in NSCLC}

In order to detect ALK rearrangement in NSCLC, methods such as FISH, IHC and reverse transcriptase RT-PCR are used ${ }^{1,14,15}$. Every method has its own advantages and limitations ${ }^{16}$. Today, FISH method using break-apart probes is accepted as the gold standard, and its use is approved by the food and drug administration (FDA) to identify ALK-rearranged NSCLC ${ }^{17}$. Despite many advantages, the ALK FISH test has also several limitations. It requires well-established laboratories with an experienced operator, and its cost is high. IHC is an easier and less expensive method, usually available in local laboratories, based on the use of ALK-specific monoclonal antibody.

Many studies suggested a marked correlation between ALK-rearrangement positivity, as detected by FISH, and ALK protein overexpression, as detected by IHC. These findings imply that IHC could be used for screening of ALK rearrangements prior to FISH, leading to the development of new diagnostic algorithms, and this must be validated in large scale concordance studies. In conclusion, RT-PCR is the most sensitive method of detecting not only $A L K$ re-arrangements, but also of determining their variant types, and the abundance of EML4-ALK positive cells in NSCLC tumor tissue. Its another advantage is requirement of limited amount of material for analysis and it is rather easy to perform, however the development of this method as a diagnostic tool has several limitations ${ }^{16}$.

\section{ALK Targeted Treatment in NSCLC}

\section{First generation of ALK inhibitors:}

Crizotinib, an oral small-molecule tyrosine kinase inhibitor (TKI) of ALK, MET and ROS1 kinases, is a first-generation ALK inhibitor ${ }^{18}$. In 2011, US FDA approved crizotinib for treating ALK-positive NSCLC. It was also approved by the European Committee for Medicinal Products for Human Use in 2015 for NSCLC patients as the standard first-line treatment. Crizotinib has a longer PFS and approximately 53$65 \%$ better objective response rate (ORR) compared to chemotherapy ${ }^{19}$. It was reported that patients acquire drug resistance within the first year following the initial use of crizotinib ${ }^{20}$.

The mechanisms of crizotinib resistance were suggested to involve point mutations, fusion gene amplification, and activation of bypass signaling via activation of other oncogenes including EGFR, MAP kinse-ERK kinase $(\mathrm{MEK})$, extracellular signal regulated kinase (ERK), SRC proto-oncogene (SRC) and insulin-like growth factor-1 receptor (IGF-1R) ${ }^{21}$. Particularly, there were two mechanisms noticed in about $33 \%$ of patients who developed the secondary point mutation after treatment with crizotinib. Several point mutations were detected including G1269A, F1174L, L1152R, S1206Y, 1151Tins, I1171T, D1203N, V1180L, C1156Y, F1164V, G1202R, G1269S 22 . The most common of these mutations are L1196M and G1269 $\mathrm{A}^{23}$.

\section{Second generation of ALK inhibitors:}

The purpose of second-generation ALK inhibitors was to refrain from the CNS progression caused by first-generation ALK inhibitors that occurs in approximately $70 \%$ of the NSCLC patients who has brain metastasis ${ }^{24}$. Besides, they were developed as a result of the need to improve PFS efficacy. Secondgeneration ALK inhibitors include ceritinib, alectinib, brigatinib, entrectinib, X-396 and TSR-011 ${ }^{25}$. Among these, ceritinib and alectinib were recently approved by FDA for the treatment of ALK-rearranged NSCLC. The second-generation ALK inhibitors could hinder 
Table 2. Resistance mechanisms in ALK targeted treatment

\begin{tabular}{lll}
\hline ALK-dominant mechanisms & ALK non-dominant mechanisms \\
\hline Secondary point mutations & Partially ALK-dependent & ALK-independent \\
L1196M, C1156Y, L1152R, 1151Tins, G1202R, S1206Y, F1174C, D1203N, G1269A, L1196M & KIT amplification & EGFR mutation \\
ALK-CNG (Copy number gain) & MET amplification & KRAS mutation \\
& & Autophagy \\
\hline
\end{tabular}

the resistance mutations which occur due to the firstgeneration inhibitor crizotinib, and increase the potency against central nervous system diseases ${ }^{26}$. Yet, treatment with the second-generation ALK inhibitors also results in drug resistance and tumor recurrence ${ }^{27}$. Ceritinib was approved by FDA in 2014 for the treatment of NSCLC. This small molecule is an oral tyrosine kinase inhibitor of ALK and exhibits an ATPcompetitive action ${ }^{28}$.

The most common resistant mutations occurring due to ceritinib include G1202R and F1174L ${ }^{29}$. C1156Y, 1151Tins and L1152R secondary mutations were also found to be related with resistance caused by ceritinib $^{30}$. Brigatinib is an inhibitor acting on ALK and EGFR and it was found to hinder mutations resistant to crizotinib such as ALK L1196M and the gatekeeper mutation T790M of EGFR ${ }^{31}$.

3. The third generation of ALK inhibitors:

Second-generation ALK inhibitors may cause tumor reccurence and cerebral metastases. Lorlatinib is a more efficient ALK/ROS1 inhibitor and a phase 2 clinical trial has been conducted on it. There is evidence obtained from in vitro studies that Lorlatinib had better therapeutic potency compared with the secondary ALK mutations caused by crizotinib ${ }^{32}$. It has been recently reported that $\mathrm{L} 1198 \mathrm{~F}$ mutation is resistant to lorlatinib primarily via steric interference with drug binding. Other studies reported that L1198F could promote the crizotinib binding, diminish the $\mathrm{C} 1156 \mathrm{Y}$ effect, and re-sensitize resistance to crizotinib ${ }^{33}$. It appears that the combination of lorlatinib and PI3K pathway inhibitors exhibit more potency in reducing ALK mutations and ALK inhibitor resistance ${ }^{22}$, however clinic impacts or resistance mechanisms of lorlatinib should be further studied to overcome L1198F.

\section{Resistance Mechanisms in ALK Targeted Treatment of NSCLC}

Although crizotinib has a perfect efficacy in ALKpositive lung cancer cases, almost all patients show resistance to crizotinib sooner or later. Mechanisms of this resistance can be divided into two major groups: ALK-dominant or ALK non-dominant. The various mechanisms submitting intrinsic or acquired resistance to crizotinib are presented in Table 2.

\section{Novel Strategies to Overcome Resistance}

Two distinct strategies with ongoing phase I/II clinical studies on crizotinib resistance are new generation ALK inhibitors (e.g., AP26113, LDK378, and CH5424802) and heat shock protein 90 inhibitors (e.g., STA-9090, IPI-504, and AUY922). New generation ALK inhibitor effectively inhibits ALK kinase and show activity against most of the resistance mechanisms in in vivo/in vitro tests ${ }^{16}$. HSP90 inhibitors are not specific to ALK, however they can overcome crizotinib resistance by diminishing folding in oncogenic proteins including ALK fusion proteins. In other cases with oncogenic drivers activation, ALK dual inhibition and changing enzymes take over in potential treatment strategies ${ }^{16}$.

\section{Conclusion}

Accumulating information about cancer biology and oncogenic drivers has provided the scientists a better comprehension of lung cancer and introduction of efficient targeted therapies. Evidence supports that ALK inhibitors can help ALK-positive NSCLC patients, however inevitable drug resistance remains as a problem. Thanks to clear understanding of ALK-positive cancer-specific pathophysiology, better therapy for patients with lung cancer and reduced resistance can be achieved by improvement of ALK inhibitors. Gene heterogeneity, mutation number and location have a significant role in mechanisms of resistance, where the resistance of one inhibitor develops due to multiple mutations and factors, or some inhibitors sue to another factor. One of clinical difficulties is efficient and precise assessment of drug resistance to ALK inhibitors in order to improve the treatment during disease progression $^{34}$. Further studies will focus on optimal diagnosis and treatment at earlier stages of disease, also on rational 
combinations of effective agents and the ideal treatment regime, especially as more next-generation agents are being approved. Besides, ideal supportive care and toxicity management is crucial for the cancer cases who may hopefully have a better survival on sequential treatment.

\section{References}

1. Reungwetwattana T, Dy GK. Targeted therapies in development for non-small cell lung cancer. J Carcinog 2013;12:22.

2. Aisner DL, Marshall C. Molecular pathology of non-small cell lung cancer: a practical guide. Am J Clin Pathol 2012;138:332-46.

3. Vijayalakshmi R, Krishnamurthy A. Targetable "driver" mutations in non small cell lung cancer. Indian J Surg Oncol 2011;2:178-88.

4. Shackelford RE, Vora M, Mayhall K, Cotelingam J. ALKrearrangements and testing methods in non-small cell lung cancer: a review. Genes Cancer 2014;5:1-14.

5. Pikor LA, Ramnarine VR, Lam S, Lam WL. Genetic alterations defining NSCLC subtypes and their therapeutic implications. Lung Cancer 2013;82:179-89.

6. Roskoski R Jr. Anaplastic lymphoma kinase (ALK): structure, oncogenic activation, and pharmacological inhibition. Pharmacol Res 2013;68:68-94.

7. Morris SW, Kirstein MN, Valentine MB, Dittmer K, Shapiro DN, Look AT, et al. Fusion of a kinase gene, ALK, to a nucleolar protein gene, NPM, in non-Hodgkin's lymphoma. Sci 1994:263(5151):1281-4.

8. Soda M, Choi YL, Enomoto M, Takada S, Yamashita Y, Ishikawa S, et al. Identification of the transforming EML4-ALK fusion gene in non-small-cell lung cancer. Nature 2007;448:561-6.

9. Zhang X, Zhang S, Yang X, Yang J, Zhou Q, Yin L, et al. Fusion of EML4 and ALK is associated with development of lung adenocarcinomas lacking EGFR and KRAS mutations and is correlated with ALK expression. Mol Cancer 2010;9:188.

10. Sasaki T, Rodig SJ, Chirieac LR, Janne PA. The biology and treatment of EML4-ALK non-small cell lung cancer. Eur J Cancer 2010;46(10):1773-80.

11. Wangari-Talbot J, Hopper-Borge E. Drug Resistance Mechanisms in Non-Small Cell Lung Carcinoma. J Can Res Updates 2013;2:265-82.

12. Tanimoto A, Yamada T, Nanjo S, Takeuchi S, Ebi H, Kita K, et al. Receptor ligand-triggered resistance to alectinib and its circumvention by Hsp90 inhibition in EML4-ALK lung cancer cells. Oncotarget 2014;5:4920-8.

13. Takeda M, Okamoto I, Sakai K, Kawakami H, Nishio K, Nakagawa K. Clinical outcome for EML4-ALK-positive patients with advanced non-small-cell lung cancer treated with first-line platinum-based chemotherapy. Ann Oncol 2012;23:2931-6.

14. Bang YJ. Treatment of ALK-positive non-small cell lung cancer. Arch Pathol Lab Med 2012;136:1201-4.

15. Vijayvergia N, Mehra R. Clinical challenges in targeting anaplastic lymphoma kinase in advanced non-small cell lung cancer. Cancer Chemother Pharmacol 2014;74:437-46.

16. Rolfo C, Passiglia F, Castiglia M, Raez LE, Germonpre P, Gil-Bazo I, et al. ALK and crizotinib: after the honeymoon...what else? Resistance mechanisms and new therapies to overcome it. Transl Lung Cancer Res 2014;3:250-61.

17. Gridelli C, Peters S, Sgambato A, Casaluce F, Adjei AA, Ciardiello F. ALK inhibitors in the treatment of advanced NSCLC. Cancer Treat Rev 2014;40:300-6.
18. Ou SH, Kwak EL, Siwak-Tapp C, Dy J, Bergethon K, Clark JW, et al. Activity of crizotinib (PF02341066), a dual mesenchymalepithelial transition (MET) and anaplastic lymphoma kinase (ALK) inhibitor, in a non-small cell lung cancer patient with de novo MET amplification. J Thorac Oncol 2011;6(5):942-6.

19. Solomon BJ, Mok T. First-line crizotinib in ALK-positive lung cancer. N Engl J Med 2015;372(8):782.

20. Forde PM, Rudin CM. Crizotinib in the treatment of non-smallcell lung cancer. Expert Opin Pharmacother 2012;13(8):1195201.

21. Katayama R, Shaw AT, Khan TM, Mino-Kenudson M, Solomon BJ, Halmos B, et al. Mechanisms of acquired crizotinib resistance in ALK-rearranged lung Cancers. Sci Transl Med 2012;4(120):120ra17.

22. Wu J, SavoojiJ, Liu D. Second-and third-generation ALK inhibitors for non-small cell lung cancer. J Hematol Oncol 2016;9:19.

23. Doebele RC, Pilling AB, Aisner DL, Kutateladze TG, Le AT, Weickhardt AJ, et al. Mechanisms of resistance to crizotinib in patients with ALK gene rearranged non-small cell lung cancer. Clin Cancer Res 2012;18(5):1472-82.

24. Costa DB, Shaw AT, Ou SH, Solomon BJ, Riely GJ, Ahn MJ, et al. Clinical Experience With Crizotinib in Patients With Advanced ALK-Rearranged Non-Small-Cell Lung Cancer and Brain Metastases. J Clin Oncol 2015;33(17):1881-8.

25. Song Z, Wang M, Zhang A. Alectinib: a novel second generation anaplastic lymphoma kinase (ALK) inhibitor for overcoming clinically-acquired resistance. Acta Pharm Sin B 2015;5(1):34-7.

26. Sassier M, Mennecier B, Gschwend A, Rein M, Coquerel A, Humbert X, et al. Successful treatment with ceritinib after crizotinib induced hepatitis. Lung Cancer 2016;95:15-6.

27. Ou SH, Milliken JC, Azada MC, Miller VA, Ali SM, Klempner SJ. ALK F1174V mutation confers sensitivity while ALK I1171 mutation confers resistance to alectinib. The importance of serial biopsy post progression. Lung Cancer 2016;91:70-2.

28. Marsilje TH, Pei W, Chen B, Lu W, Uno T, Jin Y, et al. Synthesis, structure-activity relationships, and in vivo efficacy of the novel potent and selective anaplastic lymphoma kinase (ALK) inhibitor 5-chloro-N2-(2-isopropoxy-5-methyl-4-(piperidin-4-yl) phenyl)N4-(2(isopropylsulfonyl) phenyl) pyrimidine-2, 4-diamine (LDK378)currently in phase 1 and phase 2 clinical trials. J Med Chem 2013;56(14):5675-90.

29. Friboulet L, Li N, Katayama R, Lee CC, Gainor JF, Crystal AS, et al. The ALK inhibitor ceritinib overcomes crizotinib resistance in non-small cell lung cancer. Cancer Discov 2014;4(6):662-73.

30. Rothschild S. New treatment options for ALK+ advanced nonsmall-cell lung cancer: critical appraisal of ceritinib. Ther Clin Risk Manag 2016;12:735-41.

31. Rossi A. Alectinib for ALK-positive non-small-cell lung cancer. Expert Rev Clin Pharmacol 2016;9(8):1005-13.

32. Zou HY, Friboulet L, Kodack DP, Engstrom LD, Li Q, West M, et al. PF-06463922, an ALK/ROS1 Inhibitor, Overcomes Resistance to First and Second Generation ALK Inhibitors in Preclinical Models. Cancer Cell 2015;28(1):70-81.

33. Shaw AT, Yeap BY, Mino-Kenudson M, Digumarthy SR, Costa DB, Heist RS, et al. Clinical features and outcome of patients with non-small-cell lung cancer who harbor EML4-ALK. J Clin Oncol 2009;27:4247-53.

34. McCoach CE, Bivona TG, Blakely CM, Doebele RC. Neoadjuvant Oncogene-Targeted Therapy in Early Stage Non-Small-Cell Lung Cancer as a Strategy to Improve Clinical Outcome and Identify Early Mechanisms of Resistance. Clin Lung Cancer 2016;17(5):466-69. 